\title{
Efektivitas Pembelajaran Berbasis Projek (PBP) terhadap Kreativitas Mahasiswa pada Matakuliah Metodologi Penelitian
}

\author{
M. Zainudin \\ Program Studi Pendidikan Matematika FPMIPA IKIP PGRI Bojonegoro \\ Jl. Panglima Polim No. 46 Bojonegoro Jawa Timur \\ e-mail: zain.akhmad@yahoo.com
}

\begin{abstract}
Abstrak. Penelitian ini dilakukan dengan tujuan untuk membuktikan efektivitas Pembelajaran Berbasis Projek (PBP) terhadap kreativitas mahasiswa pada matakuliah metodologi penelitian pendidikan. Penelitian ini merupakan penelitian eksperimental semu. Populasi dalam penelitian ini adalah seluruh mahasiswa program studi pendidikan Matematika IKIP PGRI Bojonegoro tahun akademik 2012/2013. Pengambilan sampel dilakukan dengan cara cluster random sampling, sehingga terambil 2 kelas yakni III-A yang terdiri dari 32 siswa dan VIII-C yang terdiri dari 32 siswa. Hasil penelitian ini dapat disimpulkan bahwa PBP lebih efektif daripada pembelajaran langsung terhadap kreativitas mahasiswa pada matakuliah metodologi penelitian pendidikan.
\end{abstract}

Kata kunci: Pembelajaran Berbasis Projek (PBP), metodologi penelitian, kreativitas mahasiswa.

\section{PENDAHULUAN}

Perkembangan ilmu

pengetahuan, teknologi, dan informasi yang semakin pesat di era globalisasi ini, diperlukan manusia yang berkualitas sebagai modal dasar pembangunan. Salah satu upaya untuk menyiapkan manusia yang berkualitas dapat dilakukan melalui pendidikan. Dalam rangka pembangunan manusia Indonesia seutuhnya, pembangunan bidang pendidikan merupakan sarana yang sangat baik dalam pembinaan manusia. Oleh karena itu bidang pendidikan perlu mendapat perhatian, penanganan, dan prioritas secara intensif baik oleh pemerintah, keluarga, masyarakat, dan pengelola pendidikan khususnya.

Program studi (Prodi)

Pendidikan Matematika IKIP PGRI
Bojonegoro mempunyai visi menjadi program studi Pendidikan Matematika yang mampu menghasilkan tenaga pendidik mata pelajaran matematika yang profesional, mandiri, unggul, dan berkualitas. Salah satu langkah yang dapat ditempuh untuk menghasilkan lulusan calon tenaga pendidik matematika yang kompeten adalah membekali mahasiswa prodi Pendidikan Matematika dengan matakuliah Metodologi Penelitian Pendidikan sebagai langkah untuk mempersiapkan pendidik yang mampu melakukan penelitian.

$$
\text { Tujuan }
$$

matakuliah

Metodologi Penelitian Pendidikan adalah setelah selesai mengikuti perkuliahan ini mahasiswa Program Studi Pendidikan Matematika 
diharapkan dapat menguasai konsep penelitian dan terampil meneliti, mampu menghasilkan gagasan penelitian, menulis proposal penelitian, mencatat dan menganalisis data penelitian, dan melaporkan hasil penelitian.

\section{Kompetensi Dasar (KD)}

yang harus dimiliki mahasiswa dalam perkuliahan Metodologi Penelitian Pendidikan ini adalah mahasiswa mampu memahami konsep dasar penelitian; mengidentifikasi masalah dan ide-ide untuk dikembangkan menjadi desain penelitian; menyusun proposal penelitian; terampil melakukan penelitian; menyusun laporan penelitian; memiliki kepekaan dan kemampuan mengevaluasi hasil belajar serta melakukan refleksi diri tentang praktik meneliti melalui jurnal refleksi dan portofolio sebagai mahasiswa mandiri.Terkait dengan model pembelajaran, pembelajaran yang digunakan pada mata kuliah metodologi penelitian pendidikan di IKIP PGRI Bojonegoro selama ini adalah pembelajaran langsung. Dosen aktif mentransfer pengetahuan kepada mahasiswa, sedangkan mahasiswa menerima pelajaran dengan pasif. Materi diajarkan sebagai bentuk yang sudah jadi, bukan sebagai proses. Akibatnya, ide-ide kreatif siswa tidak dapat berkembang, kurang melatih daya nalar dan tidak terbiasa melihat alternatif lain yang mungkin dapat dipakai dalam menyelesaikan suatu masalah. Mahasiswa hanya mampu mengingat dan menghafal konsep dalam metodologi penelitian tanpa memahami maknanya. Padahal dalam menghadapi perkembangan ilmu pengetahuan dan teknologi serta informasi diperlukan manusia yang memiliki keterampilan yang tinggi yang melibatkan pemikiran kritis, sistematis, logis, kreatif, dan mampu bekerjasama dengan efektif.

$$
\text { Rata-rata hasil belajar }
$$

matakuliah metodologi penelitian mahasiswa IKIP PGRI Bojonegoro tahun akademik 20111/2012 yaitu 6,7. Hasil belajar ini masih perlu ditingkatkan lagi, mengingat IKIP PGRI Bojonegoro termasuk salah satu Perguruan Tinggi (PT) yang bertujuan mengasilkan tenaga pendidik yang kompeten dalam memajukan pendidikan di Indonesia dan matakuliah metodologi penelitian pendidikan merupakan salah satu mata kuliah yang diharapkan dapat mampu menghasilkan karya-karya inovatif untuk pembangunan Indonesia.

$$
\text { Pada pembelajaran mata }
$$
kuliah metodologi penelitian pendidikan diperlukan suatu cara yang dapat mendorong ketrampilan berpikir kreatif siswa dalam menyusun pendahuluan. Terkait dengan pembelajaran yang 
selama ini pada umumnya masih menggunakan model pembelajaran langsung (direct instruction). Pembelajaran langsung (direct instruction) yang selama ini diterapkan adalah pembelajaran yang didominasi oleh dosen untuk menyampaikan materi ajar dengan tugas akhir berupa penyusunan hasil mini penelitian yang dikumpulkan sebelum UAS dan kuis yang diberikan pada pertemuan ketujuh dan kedelapan untuk mengukur penguasaan konsep dasar penelitian. Berdasarkan penelitian yang dilakukan oleh Suwono (2012: 157), Pembelajaran Berbasis Projek dapat meningkatkan hasil belajar pada matakuliah metodologi penelitian.

$$
\text { Pembelajaran Berbasis }
$$

Projek (PBP) merupakan merupakan pembelajaran otentik yang memfasilitasi mahasiswa dalam merencanakan, melaksanakan, melaporkan, dan mengevaluasi projek yang dapat diterapkan dalam kehidupan sehari-hari (Railsback, 2002). Mahasiswa didorong untuk menjalankan projek dan bekerja secara kolaboratif untuk menjalankan satu seri tugas (projek) yang pada akhirnya menghasilkan suatu produk pada akhir projek (Anonim, 2009; Petrosina, 2009), dalam hal ini adalah proposal penelitian.
PBP melatih mahasiswa untuk bekerja secara kolaboratif, yang merupakan keterampilan yang diperlukan ketika memasuki dunia kerja. Mahasiswa bekerja di dalam tim sehingga belajar untuk mengembangkan keterampilan dan kreativitas dalam merencanakan projek, mengorganisasikan tim untuk melaksanakan projek, melakukan negosiasi dan membuat konsensus tentang isu-isu atau tugas yang akan dikerjakan serta bertanggung jawa dalam sebuah tim.

\section{Railsback}

menyatakan bahwa keutungan PBP adalah untuk menyiapkan mahasiswa masuk dalam dunia kerja yag nyata, misalnya bekerja sma, merencanakan pekerjaan, mengambil keputusan, dan mengelola waktu. Kamdi (2008) menyatakan bahwa PBP dapat meningkatkan hasil belajar karena memiliki kelebihan, seperti: PBP otentik kontekstual yang akan akan memperkuat hubungan antara aktivitas dan pengetahuan konseptual yang melatarinya; mengedepankan otonomi mahasiswa; proses belajar koaboratif yang memberikan peluang mahasiswa saling membelajarkan; holistik dan interdisipliner; realistik, berorientasi memecakan permasalahan riil; dan memeberikan pengetahuan intrinsik 
tyang dapat menajamkan kecakapan berpikir produktif.

Kecakapan berpikir dalam penelitian ini difokuskan pada cara berpikir kreatif mahaisswa. Cara berpikir kreatif merupakan suatu proses yang digunakan seseorang dalam mensintesis (menjalin) ide-ide, membangun ide-ide baru dan menerapkannya untuk menghasilkan produksi yang baru secara fasih dan fleksibel. Berpikir kreatif merupakan kegiatan mental untuk menemukan "ide baru" yang sesuai dengan tujuan, dengan cara mensintesis ide-ide, membangun (generating) ide-ide, dan menerapkannya (Siswono, 2008: 10). Berpikir kritis juga dapat diartikan sebagai suatu kombinasi dari berpikir logis dan berpikir divergen yang didasarkan pada intuisi tetapi masih dalam kesadaran (Pehkonen, 1997).

Krulik dan Rudnick (1999), yang menjelaskan bahwa berpikir kreatif merupakan pemikiran yang bersifat keaslian dan reflektif dan menghasilkan suatu produk yang komplek., silver (1997) menjelaskan bahwa untuk menilai berpikir kreatif anak-anak dan orang dewasa sering digunakan "The Tourence Test of Creative Thingking (TTCT)". tiga komponen kunci yang dinilai dalam kreativitas menggunakan TTCT adalah kefasihan (fluency), fleksibilitas dan kebaruan (orisinilitaas). kefasihan mengacu pada banyaknya ideide yang dibuat dalam merespon sebuah perintah. fleksibilitas tampak pada perubahan-perubahan pendekatan ketika merespon perintah. kebaruan merupakan keaslian ide yang dibuat dalam merespon perintah. Hasil dari berpikir kreatif sering disebut kreativitas. Kreativitas merupakan kemampuan seseorang menghasilkan sesuatu (soal, masalah atau pengetahuan) yang pada dasarnya baru dan sebelumnya tidak dikenal oleh pembuatnya serta berbeda dari sesuatu (soal, masalah atau pengetahuan) lain yang dibuat berdasar sebuah informasi. kreativitas ditinjau dari berdasar kefasihan (fluency), fleksibilitas dan kebaruan (orisinilitaas). kreativitas dalam matematika menurut Krutetskii dalam (Siswono, 2008) merupakan kemampuan (abilities) peserta didik yang berhubungan dengan suatu penguasaan kreatif mandiri matematika di bawah pengajaran matematika, formulasi mandiri masalahmasalah matematis yang tidak rumit, penemuan cara-cara dan sarana dari penyelesaian masalah, penemuan buktibukti teorema, pendeduksian mandiri rumus-rumus dan penemuan metodemetode asli penyelesaian masalah non standar. salah satu cara yang mungkin dapat digunakan untuk mengoptimalkan 
keterampilan dalam berpikir kreatif adalah dengan pemecahan masalah dan pengajuan masalah.

Pembelajaran dalam

Metodologi Penelitian Pendidikan ini diarahkan untuk mengembangkan aktivitas kreatif yang melibatkan imajinasi, intuisi, dan penemuan dengan mengembangkan pemikiran divergen, orisinil, rasa ingin tahu, membuat prediksi dan dengan mencoba-coba. Selain itu dalam aspek pemikiran kreatif dalam merumuskan dan menyelesaikan model atau perencanaan pemecahan masalah. Sehingga diperlukan suatu cara yang dapat mendorong ketrampilan berpikir kreatif mahasiswa dalam belajar. Berdasarkan penelitian yang dilakukan oleh Siswono (2008: 66), siswa akan dapat berpikir kreatif jika diberikan kesempatan mengajukan permasalahan dan meecahkan masalah.

$$
\text { Colley }
$$

mengemukakan langkah-langkah PBP meliputi mengidentifikasi dan mendefinisikan projek, mencari informasi, merencanakan projek, melaksanakan projek, mendokumtasikan dan melaporkan penemuan, dan mengevaluasi projek. Oleh karena itu, dalam matkuliah Metodologi Penelitian, PBP memfasilitasi mahasiswa merancang, melaksanakan, melaporkan projek penelitian, serta merefleksikannya dalam hasil belajarnya. Dalam melakukan penelitian, mahasiswa berlatih mengidentifikasi masalah, merumuskan hipotesis, mengembangkan rancangan penelitian, mengumpulkan data, menganalisis data, mengumpulkan data, menganalisis data, menarik kesimpulan, mengkomunikasikan penemuan, serta menulis laporan penelitian.

Penelitian ini bertujuan untuk membuktikan efektivitas Pembelajaran Berbasis Projek (PBP) terhadap kreativitas mahasiswa pada mata kuliah Metodologi Penelitian Pendidikan. Kretivitas mahasiswa dalam matakuliah Metodologi Penelitian Pendidikan yang dinilai pada matakuliah ini adalah hasil penyusunan proposal dan laporan hasil mini penelitian.

\section{METODE PENELITIAN}

Penelitian efektivitas Pembelajaran Berbasis Projek (PBP) terhadap Kreativitas Mahasiswa pada Matakuliah Metodologi Penelitian ini merupakan penelitian eksperimental semu. Penelitian dilaksanakan pada mahasiswa program studi (Prodi) Pendidikan Matematika IKIP PGRI Bojonegoro pada semester ganjil 2012/2013. Materi penelitian meliputi penyususnan proposal penelitian, pelaksanaan mini penelitian, penyusunan laporan penelitian. 
Perbedaan perlakuan pada kelas fleksibilitas dan kebaruan (orisinilitaas), eksperimen dengan kontrol yakni dan rubrik penilaian penyusunan laporan pembelajaran pada kelas eksperimen menggunakan PBP sehingga hasil penilaian.

Data kreativitas penyusunan penyusunan proposal dan laporan hasil mini penelitian pada kelas eksperimen dikontrol setiap pertemuan sehingga pada kelas kontrol dikenai pembelajaran langsung dengan tugas penyusunan proposal diserahkan pada pertemuan kedelapan dan laporan mini penelitian diserahkan kepada dosen pada pertemuan keenambelas, sedangkan pada setiap perkuliahan dosen menyampaikan materi penelitian dan laporan hasil penelitian secara terperinsi dan mahasiswa diberikan kebebasan untuk mengaplikasikan konsep penelitian dan laporan hasil penelitian berdasarkan informasi dan pengetahuan dari setiap tatap muka selama perkuliahan matakuliah Metodologi Penelitian Pendidikan.

Data dan instrumen yang dikumpulkan dalam penelitian ini adalah data hasil kreativitas mahasiswa dalam menyusun proposal dan menyusun laporan hasil penelitian. Data tersebut dikumpulkan dengan instrumen berupa soal uraian tentang perintah penyusunan proposal dan pelaporan hasil penelitian, rubrik penilaian kreativitas mahasiswa dalam penyusunan proposal yang tersusun dari kefasihan (fluency), proposal penelitian dan laporan hasil mini penelitian dianalisis untuk mengetahui tingkat kreativitas mahasiswa. Kreativitas mahasiswa dalam menyusun laporan dan hasil penelitian yang meliputi tiga aspek, yakni kefasihan (fluency), fleksibilitas dan kebaruan (orisinilitaas) pada proposal dan laporan hasil penelitian dihitung dalam skor rerata kreativitas mahasiswa.

\section{HASIL DAN PEMBAHASAN}

Hasil

Fokus efektivitas Pembelajaran Berbasis Projek (PBP) terhadap Kreativitas Mahasiswa pada Matakuliah Metodologi Penelitian adalah kreativitas mahasiswa dalam menyusun laporan dan laporan hasil penelitian. Sebelum diberikan perlakuan yang berbeda (manipulasi) terhadap variabel bebas, dilakukan uji keseimbangan rerata kemampuan awal mahasiswa pada kelas eksperimen dan kelas konrol menggunakan data Indeks Prestasi Mahasiswa Semester I sampai IV dengan tujuan agar setelah dilakukan suatu penelitian dengan memberikan perlakuan berbeda (manipulasi variabel bebas), dapat dipastikan bahawa ada 
tidaknya perbedaan rerata siswa bukan

Lilliefors

dan

homogenitas

karena kemampuan awal siswa sudah menggunakan metode Bartlett. Masingberbeda tetapi karena perbedaan masing uji prasyarat menggunakan perlakuan yang diberikan. Pada penelitian ini uji keseimbangan menggunakan t-test dengan prasyarat tingkat signifikansi $5 \%$. Berdasarkan analisis uji normalitas dan perhitungannya diperoleh rangkuman normalitas menggunakan metode hasil sebagai berikut :

Tabel 1 rangkuman hasil uji normalitas

\begin{tabular}{lccll}
\hline \multicolumn{1}{c}{ populasi siswa } & $\mathbf{l}_{\text {observasi }}$ & $\mathbf{l}_{\text {kritik }}$ & keputusan uji & data berdistribusi \\
\hline PBP & 0,074954 & 0,156624 & $\mathrm{H}_{0}$ diterima & Normal \\
\hline $\begin{array}{l}\text { Pembelajaran } \\
\text { Langsung }\end{array}$ & 0,079531 & 0,156624 & $\mathrm{H}_{0}$ diterima & Normal \\
\hline
\end{tabular}

\section{Berdasarkan keputusan uji} pada Tabel 1, maka dapat disimpulkan bahwa kedua populasi siswa berdistribusi normal. kemudian dilanjutkan uji prasyarat keseimbangan berikutnya, yakni homogenitas menggunakan uji Bartlett dengan tingkat signifikansi 5\%. Berdasarkan analisis uji homogenitas antara kelas eksperimen dengan kelas kontrol diperoleh harga $\chi^{2}{ }_{\text {hitung }}$ sebesar 2,2697 dan $\chi^{2}$ tabel sebesar 3,841 , karena $\chi^{2}$ hitung kurang dari $\chi_{\text {tabel }}^{2}$ maka $\mathrm{H}_{0}$ diterima, sehingga dapat disimpulkan variansi populasi homogen.

$$
\text { Setelah data berdistribusi }
$$
normal dan variansinya homogen, dilanjutkan uji keseimbangan menggunakan t-test. Berdasarkan analisis uji keseimbangan antara kelas eksperimen dengan kelas kontrol diperoleh harga $t_{\text {hitung }}$ sebesar 1,027413 dan $t_{\text {tabel }}$ sebesar 1,96 , karena $t_{\text {hitung }}$ kurang dari $\mathrm{t}_{\text {tabel }}$ maka $\mathrm{H}_{0}$ diterima, sehingga dapat disimpulkan populasi seimbang atau memiliki kemampuan awal yang sama.

Data hasil penelitian yang didapat setelah perlakuan kemudian diuji normalitasnya menggunakan metode Lilliefors dengan tingkat signifikansi 5\%. Berdasarkan analisis uji normalitas dan perhitungannya diperoleh rangkuman hasil sebagai berikut :

Tabel 2 rangkuman hasil uji normalitas

\begin{tabular}{lcccc}
\hline \multirow{2}{*}{ populasi siswa } & $\mathbf{l}_{\text {observasi }}$ & $\mathbf{l}_{\text {kritik }}$ & keputusan uji & data berdistribusi \\
\hline \hline PBP & 0,110459 & 0,156624 & $\mathrm{H}_{0}$ diterima & Normal
\end{tabular}


Berdasarkan Tabel 2 dapat disimpulkan bahwa data-data berasal dari populasi yang berdistribusi normal, artinya mahasiswa yang mendapat skor kreativitas jelek dan yang bagus relatif sedikit sedangkan nilai yang paling banyak berada pada rerata data tersebut. Prasyarat berikutnya adalah homogenitas. Uji homogenitas sebagai prasyarat uji hipotesis pada penelitian ini menggunakan metode Bartlett. Berdasarkan analisis uji homogenitas antara kelas eksperimen dengan kelas kontrol pada nilai setelah dilakukan manipulasi terhadap variabel bebasnya diperoleh diperoleh harga $\chi^{2}{ }_{\text {hitung }}$ sebesar 0,4965 dan $\chi^{2}$ tabel sebesar 3,841, karena $\chi^{2}$ hitung kurang dari $\chi_{\text {tabel }}^{2}$ maka $\mathrm{H}_{0}$ diterima, sehingga dapat disimpulkan variansi populasi homogen.

Terpenuhinya kedua syarat uji perbedaan yakni normalitas dan homogenitas maka dapat dilakukan uji hipotesis. Uji hipotesis pada penelitian ini menggunakan t-test dengan tingkat signifikansi 5\%. Berdasarkan analisis data menggunakan t-test antara kelas eksperimen dengan kelas kontrol diperoleh harga $t_{\text {hitung }}$ sebesar 2,091152 dan $t_{\text {tabel }}$ sebesar 1,96, karena $t_{\text {hitung }}$ lebih besar daripada $t_{\text {tabel }}$ maka $\mathrm{H}_{0}$ ditolak, sehingga dapat disimpulkan bawa terdapat perbedaan secara signifikan antara kreativitas siswa yang diajar menggunakan PBP dan pembelajaran langsung. Berdasarkan analisis dapat dapat diketahui bahwa rerata dari nilai kreativitas siswa yang diajar menggunakan PBP sebesar 82,59. Sedangkan rerata nilai kreativitas siswa yang diajar dengan model pembelajaran Langsung sebesar 77,69, hal ini berati mahasiswa yang diajar menggunakan PBP menghasilkan kreativitas yang lebih baik daripada mahsiswa dengan pembelajaran Langsung atau dengan kata lain PBP lebih efektif daripada pembelajaran langsung terhadap kreativitas mahasiswa pada matakuliah Metodologi Penelitian Pendidikan.

\section{Pembahasan}

Pada hasil tes kreativitas mahasiswa yang diajar dengan PBP lebih kreatif dapat memecahkan permasalahan penelitian dengan berbagai macam alternatif dan mampu mengidentifikasi permasalahan pendidikan secara holistik sehingga indikator berpikir kreatif yakni kefasihan, fleksibilitas, dan kebaruan terpenuhi. Sedangkan pada siswa yang diajar dengan pembelajaran pembelajaran langsung cenderung kurang kreatif karena ada kemungkinan 
mahasiswa menyelesaikan proposal seketika atau dalam waktu batas akhir pengumpulan tugas akibatnya banyak proposal yang bukan berisi ide baru dalam mengatasi permasalahan pendidikan. Kriteria produk kreativitas yang sukar ditemui adalah fleksibilitas. Mahasiswa pada umumnya tidak membuat proposal yang memuat berbagai macam alternatif penyelesaian masalah pendidikan atau hanya menyebutkan satu alternatif penyelesaian masalah yang diangkat dalam proposal tersebut.

$$
\text { Pembelajaran PBP lebih }
$$
menekankan untuk mahasiswa aktif dalam mengembangkan potesi yang dimiliki seperti kemampuan menganalisis masalah, menjalin ide-ide, memecahkan masalah, bahkan sampai mengungkapokan permasalahan riil dapat ditemui dalam dunia pendidikan. Akibatnya mahasiswa akan terbiasa melakukan penelitian dan melatih bersosial dengan baik karena tidak menuntut kemungkinan untuk mengkonfirmasi masalah yang akan diselesaikan dalam penelitian, mahasiswa terjun langsung ke lapangan.. Sedangkan siswa yang diajar dengan pembelajaran Langsung akan terbatas dalam mengembangkan potensi yang dimiliki karena waktu yang diberikan mahasiswa cukup sedikit meskipun mahasiswa dapat memperdalam pengetahuan di luar pembelajaran akan tetapi hal tersebut akan lebih maksimal jika dalam pembelajaran mahasiswa diberikan waktu yang lebih untuk mengembangkan potesi yang dimilikinya sehingga dosen dapat mengambil tindakan yang dapat merangsang kreativitas mahasiswa untuk mengoptimalkan kemampuannya.

\section{SIMPULAN}

Berdasarkan hasil penelitian dan analisa data yang telah dilakukan, maka dapat disimpulkan bahwa PBP lebih efektif daripada pembelajaran langsung terhadap kreativitas mahasiswa pada matakuliah Metodologi Penelitian Pendidikan

\section{DAFTAR PUSTAKA}

Anonim. (2009). Project-Bassed Instruction and Learning in Adult Education. A Publication of Building Profesional Development, Partnerships for Adult Educators Project (PRO-NET). Pelavin Research.

Colley, K. (2008). Project-Based Sciense Instruction. The Science Teacher, 74(8):23-28.

Kamdi, W. (2008). Project-Based Learning: Pendekatan Pembelajaran Inovatif. Makalah disampaikan dalam Pelatihan Penyusunan Bahan Ajar Guru SMP dan SMA Kota Tarakan, 31 Oktober s.d. November.

Krulik, Stephen \& Rudnick, Jesse A. (1995). The New Sourcebook 
for Teaching Reasoning and Problem Solving in Elementary School. Needham Heights, Massachusetts: Allyn \& Bacon.

Pehkonen, Erkki. (1997). The State-ofArt in Mathematical Creativity., Vol. 29, No. 3, 230-245.

Petrosina, A. (2009). Project-BasedLearning: Background Knowledge and Theory. Madison: Wisconsin Center for Education Research.

Railsback, J. (2002). Project-BasicLearning: Creating Excitemen for Learning. Northwest Regional Educational Laboratory.

Silver, Edward A. (1997). Fostering Creativity Through Instruction Rich in Mathematical Problem Solving and Thinking in Problem Posing. Vol. 29, No. 3, 237-289.

Siswono, Tatag Yuli Eko. (2008). Kumpulan Karya 2005-2007. Surabaya: UNESA press. 